\title{
Global Paradigm for Intellectual Leadership of Countries
}

\author{
IRYNA KALENYUK ${ }^{1}$, \\ LIUDMYLA TSYMBAL ${ }^{2}$
}

\begin{abstract}
The methodological approaches to the study of the phenomenon of intellectual leadership of national economies and the imperatives of its manifestation in the global economic environment have been analyzed and generalized in the article. The formation of a new global system based on knowledge and information is accompanied by rapid change and significant stratification of the competitive environment. Systemic global interdependence generates new factors for the competitiveness of market participants, determining their appropriate strategic behavior to ensure high competitiveness and leadership, which, on the one hand, becomes a key component of public economic policies and effective management, and on the other hand becomes the subject of special interdisciplinary research. The mechanisms of intellectualization and the growing role of intellectual factors in the formation of the knowledge economy have been identified. There is a gradual increase in the influence of intellectualization on the formation of the post-industrial model of world economic development in the modern economic environment, deepening of the penetration of intellectualization in economic processes and the formation of complex economic systems, transformation of the human role in the paradigm of global development, which raises the issue of study of the development of the global economic space and its key features. The lack of unity in the interpretation of the essence of intellectual leadership and its subjects have been noticed in the process of generalization of theoretical positions, thus it was confirmed multi-structural, contradictory, transdisciplinary nature of this phenomenon, which is becoming the subject of study of not only psychology and management, its nature is changing, and moreover, its role is changing in the modern environment.

The economic dimensions of global intellectualization have been revealed on the basis of a three-stage assessment: firstly - the resource level (accumulated logistical, financial, human and intellectual potential); secondly - the level of intermediate results of intellectual activity (of scientific and educational, technological, infrastructural, production, service, market nature); thirdly - the level of the final results of the overall progress (dynamics of general economic indicators, positions in world rankings and indices, etc.). The influence of the intellectual component on the final macroeconomic indicators and the international competitiveness of national economies has been studied. The disposition of countries in the global economic environment has been determined and paradigmatic principles of effective involvement of national economies in the global processes of intellectualization have been formed. Four clusters of countries have been identified on the basis of differentiation of countries according to the level of concentration in the dominant sectors of the economy, which made it possible to form models of their long-term development. Econometric modeling
\end{abstract}

\footnotetext{
* This article was translated from its original in Ukrainian.

${ }^{1}$ Kalenyuk Iryna Serhiivna - Doctor of Economics, Full Professor, Director of Scientific Research Institute of Economic Development of Kyiv National Economic University Named after Vadym Hetman. Author of more than 200 research papers. Sphere of scientific interest: intellectualization of international economic relations, internationalization process of the world economy, economic issues of education, development of human potential, education internationalization. E-mail: kalenuk@ukr.net

2 Tsymbal Liudmyla Ivanivna - Doctor of Economics, Professor at the Department of International Economics of Kyiv National Economic University Named after Vadym Hetman. Sphere of scientific interest:
} market of educational services, intellectual leadership, intellectual capital. E-mail: 1.tsimbal@ukr.net

IEP, No. 32-33 (2020), pp. 7-25

(C) Iryna Kalenyuk, Liudmyla Tsymbal, 2020 «All rights reserved»

ISSN 1811-9832/2020/No. 1-2 (32-33) 
allowed to develop a scenario forecast for Ukraine, highlighting the importance of factors of intellectual leadership securement.

KEY WORDS: intellectual leadership, intellectual leadership imperatives, intellectualization, international division of labor, research and development, high-tech exports, global market, global innovation space, innovative strategies, strategies for intellectualization of economic activity.

\section{Introduction}

Perception of leadership as a multi-aspect, multi-level, factored and functionally determined phenomenon is the basis for its modern understanding. First of all, intellectual leadership provides global success and constant progress of business organizations, countries and regions in the context of high-quality technological shifts, in particular super-dynamic digital transformations, networking of economic systems, socialization and environmentalization. In the XXI century, a new composition of its resource, scientific, technological, market and civilizational imperatives is being formed, which is most fully reflected in the sustainability of economic development, structural dynamics and global competitive dispositions of countries. At the same time, the world is in a pre-paradigm state, which is determined by the presence of certain theories of intellectual leadership research and the practice of its implementation, in the absence of a comprehensive conceptual justification.

The issue of leadership is actualized in the research of many scientists of different scientific schools. Thus, the general questions of the essence of leadership, its forms, parameters and features were considered in the works of Blanchard K. ${ }^{3}$, Blondel J. ${ }^{4}$, Weber M. ${ }^{5}$, Kets de Vries $^{6}$, Katz D. ${ }^{7}, \quad$ Kuczmarski T. ${ }^{8}$, Macfarlane A. ${ }^{9}, \quad$ Mitchell D. ${ }^{10}$, Owen H. ${ }^{11}$,

\footnotetext{
${ }^{3}$ Blanchard K. Leadership: to the pinnacle of success. SPb .: Piter, 2008. -368 p.

4 Blondel J. Political Leadership: Towards a General Analysis. London-Beverly Hills-New Delhi: SAGE Publications, 1987. $-216 \mathrm{p}$.

${ }^{5}$ Weber M. Three pure types of legitimate domination. Sociology. General historical analyzes. Policy. K.: Osnovy, 1998. - pp.156-172.

6 Ca de Vrie Manfred. The mystique of leadership. Development of emotional intelligence. M .: Alpina Publishers, 2003. - 311 p.

${ }^{7}$ Katz D. Pattern of Leadership, in J.Knutson (ed.), Handbook of Political Psychology, San Francisco: JosseyBass, 1973. - pp. 203-233

${ }^{8}$ S.Kuczmarski, T. Kuczmarski. Values-Based Leadership. Book Ends Publishing, Chicago, 2002. - 304 p.

${ }^{9}$ Macfarlane B. Intellectual Leadership. 2011. URL: https://www.kcl.ac.uk/study/learningteaching/kli/Newsand Events/Events/scap/2011/macfarlane-scap2011.pdf.

${ }_{10}$ Mitchell D., Nielsen S. Internationalization and Globalization in Higher Education. Globalization Education and Management Agendas, 2012. — pp. 3-22. URL: https://pdfs.semanticscholar.org/3e6c/1173f21907959cd4d1 fe47ab4109795f50d9.pdf

${ }_{11}$ Owen H. Vocation - Leader: A Complete Guide to Effective Leadership. Dnipropetrovsk: Balance Business Books, 2005. $-384 \mathrm{p}$.
} 
Senge P. ${ }^{12}$, Stogdill R. ${ }^{13}$, Hollander E. ${ }^{14}$ and others. As part of the factors of competitiveness of national economies and their leadership, intellectual factors, their role and effectiveness of implementation are thoroughly studied in the works of L. Antoniuk ${ }^{15}$, O. Butnik-Siverskyi ${ }^{16}$, O. Kuklin ${ }^{17}$, E. Libanova, D. Lukianenko ${ }^{18,19}$, S. Sidenko ${ }^{20}$, A. Chukhno ${ }^{21}$ and many others.

However, the complexity and disputability of the concept of leadership, on the one hand, and the dynamic variability of the characteristics of the global economic environment, on the other hand, stimulate the deepening of research in this area. The problems of motivation and effectiveness of leadership strategies require reinterpretation in the face of increasing and changing formats of competition in global markets. It is extremely important to separate and methodologically identify the concept of intellectual leadership at the micro, macro and global levels and identify and systematize its prerequisites, factors, manifestations, models, mechanisms and tools to achieve and maintain global economic development in the system of environmental imperatives. These issues are of undoubted interest to Ukraine, which has a significant unrealized intellectual potential.

The purpose of the article is to theoretically and methodologically substantiate the global paradigm of intellectual leadership in the process of formation of the knowledge economy, to develop strategic areas of intellectualization of the Ukrainian economy taking into account the challenges of the global environment.

\footnotetext{
12 Senge P., Kleiner A., Roberts C., Ross R., Smith B. The Fifth Disciplines Fieldbook: Tools and Strategies for Building a Learning Organization, New York: Doubleday/Currency, 1994.

${ }_{13}$ Stogdill R., Bass B. Handbook of Leadership. 3 Sub edition. N.Y.: Free Press, 1990. —-1184 p.

${ }^{14}$ Hollander E. Conformity, Status and Idiosyncrasy Credit. Psychological Review, 1958. No.65. — pp. 117127.

${ }^{15}$ Antonyuk L. International competitiveness and regional aspect. International Economic Policy. Vol. 2 (1). K.: KNEU, 2005. pp. 44-68.

${ }_{16}$ Butnik-Siversky O. Intellectual capital: a theoretical aspect. Intellectual capital. 2002. No.1. - pp. 16-27.

17 Kuklin O. Institutional analysis of interregional socio-economic convergence in the context of European integration: interdisciplinary methodological approach development. Baltic Journal of Economic Studies. 2019, No.5. - pp. 80-85.

${ }^{18}$ Lukyanenko D., Kolesov V., Kolot A., Stolyarchuk J. Global economic development: trends, asymmetries, regulation: a monograph (rus.. Globalnoe ekonomicheskoe razvitie: tendentsii, asimmetrii, regulirovanie: monografiya) / ed.: D. Lukyanenko, A. Poruchnik, V. Kolesov. K .: KNEU, 2013. - 466 p. [In Russian].

19 Lukyanenko D.G., Poruchnik A.M., Kolot A.M. and other. Global economy of the XXI century: human dimension: monograph (ukr. Hlobalna ekonomika XXI stolittia: liudskyi vymir: monohrafiia) / edited by Dr. Econ. Science, prof. DG Lukyanenko and Dr. of Economics, Prof. A.M. Poruchnik. K. KNEU, 2008 . — 420 p. [In Ukrainian].

${ }^{20}$ Sidenko S. A Socially Orientated Development Model of Ukraine. A Social and Solidarity Economy. The Ukrainian Choice. / Edited by Anton S. Filipenko. Cambridge Scholars Publishing. 2017. — pp.44-60.

${ }^{21}$ Chukhno A. Intellectual capital: the essence, forms and patterns of development (ukr. Intelektualnyi kapital: sutnist, formy i zakonomirnosti rozvytku). Ukraine economy (ukr. Ekonomika Ukrainy). 2002. No. 11. — pp. 48-55. [In Ukrainian].
} 


\section{Theoretical basis of formation of the concept of intellectual leadership}

There is a gradual increase in the value of intellectual characteristics of an individual in the understanding of leadership in the process of evolution and since the mid-twentieth century a change in the essence of a person has been seen, which is required due to the economic circumstances of production development. The evolutionary analysis of the concept of intellectual leadership in the context of economic researches allowed to determine that most theories (theories of the economic base, similarity of countries, growth poles, flexible specialization, global lead over competitors, etc.) confirmed the processes of strengthening the role of intelligence in assurance of the competitiveness of economic actors, there are expanding the subject base, types and forms of leadership. Generalization of theoretical concepts and approaches to understanding intellectual leadership allows to outline the range of subjects of intellectual leadership and their characteristics, that are demonstrated on several main levels and are limited to time frames (Fig. 1).

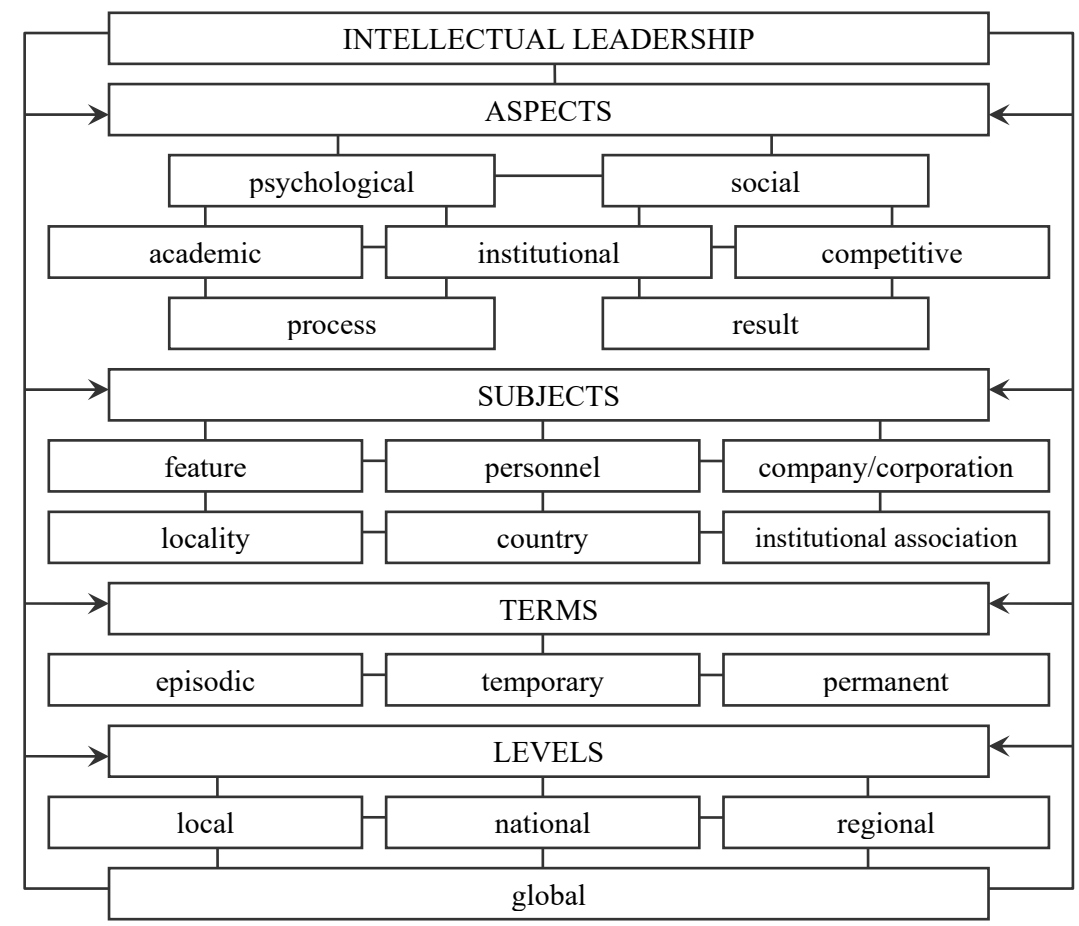

Fig. 1. Structural format of the essential characteristics of intellectual leadership ${ }^{22}$

\footnotetext{
${ }^{22}$ Developed by the authors.
} 
There is a formation of a global innovation space, in which the subjects of innovation are connected by a multilevel system of institutional, organizational, economic and social and humanitarian relations with fierce competition, constant changes in the disposition of the world.

Given that the successful integration of countries into the global economic space is impossible without active intellectualization, which has become an urgent need and a prerequisite for development at the present stage, it is worth noting the importance of intellectual leadership as part of the global economic space. According to the theoretical opinion and public practice of state administration, high positions in the global environment of the most competitive and successful states can be explained by their course for maximum intellectualization.

Analysis of the theoretical basis of intellectual leadership makes it possible to conclude that there is no methodology for the assessment of the intellectual leadership of market participant at any level. Accordingly, we can offer an author's approach, which consists in the development of a three-stage assessment algorithm: firstly - the resource level (accumulated logistical, financial, human and intellectual potential); secondly - the level of intermediate results of intellectual activity (scientific and educational, technological, infrastructural, production, service, market nature); thirdly - the level of the final results of the overall progress (dynamics of general economic indicators, positions in world rankings and indices, etc.). Such a consistent approach makes it possible to conduct a comprehensive assessment and comparison of the main functional areas of the phenomenon under study, to identify and imitate best practices in the development of innovative systems of countries-intellectual leaders. First-level leadership is defined as resource leadership, which represents the country's ability to achieve intellectual leadership by forming intellectual potential and mechanisms for building it up. Key development resources are divided into financial, human, and intellectual resources. However, the mere availability of resources determines only the opportunities for the achievement of leadership. The results of effective conversion of all available resources into capital are evaluated at the second level, where they are grouped as educational, scientific, infrastructure and technological ones (Fig. 2 and Fig. 3).

The third level of intellectual leadership is the level of end results that are manifested in connection with general economic indicators and characterize the overall progress. Intellectual leadership is manifested through the high positions of countries in indices, rankings, and the achievement of intellectual leadership can be confirmed by the 


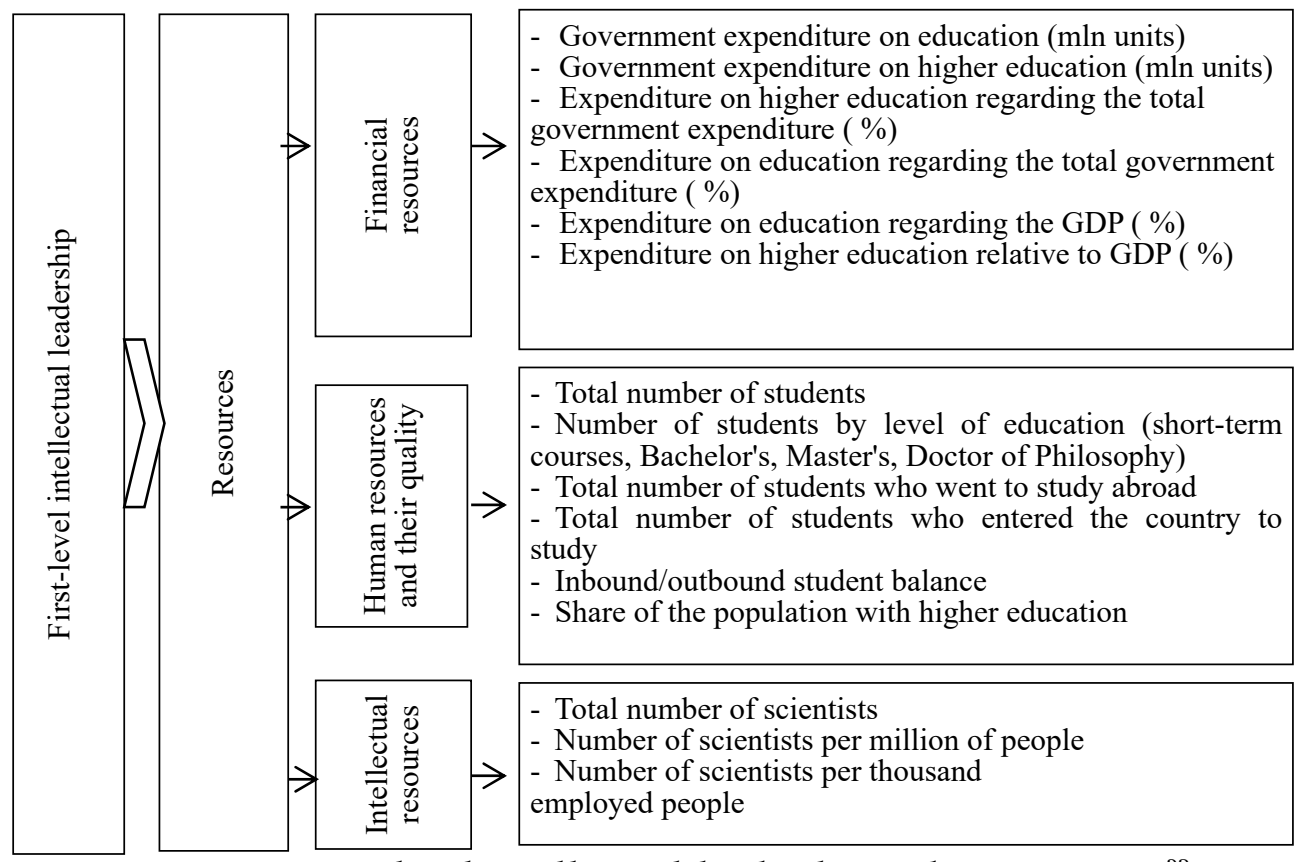

Fig. 2. First-level intellectual leadership indicator system ${ }^{23}$

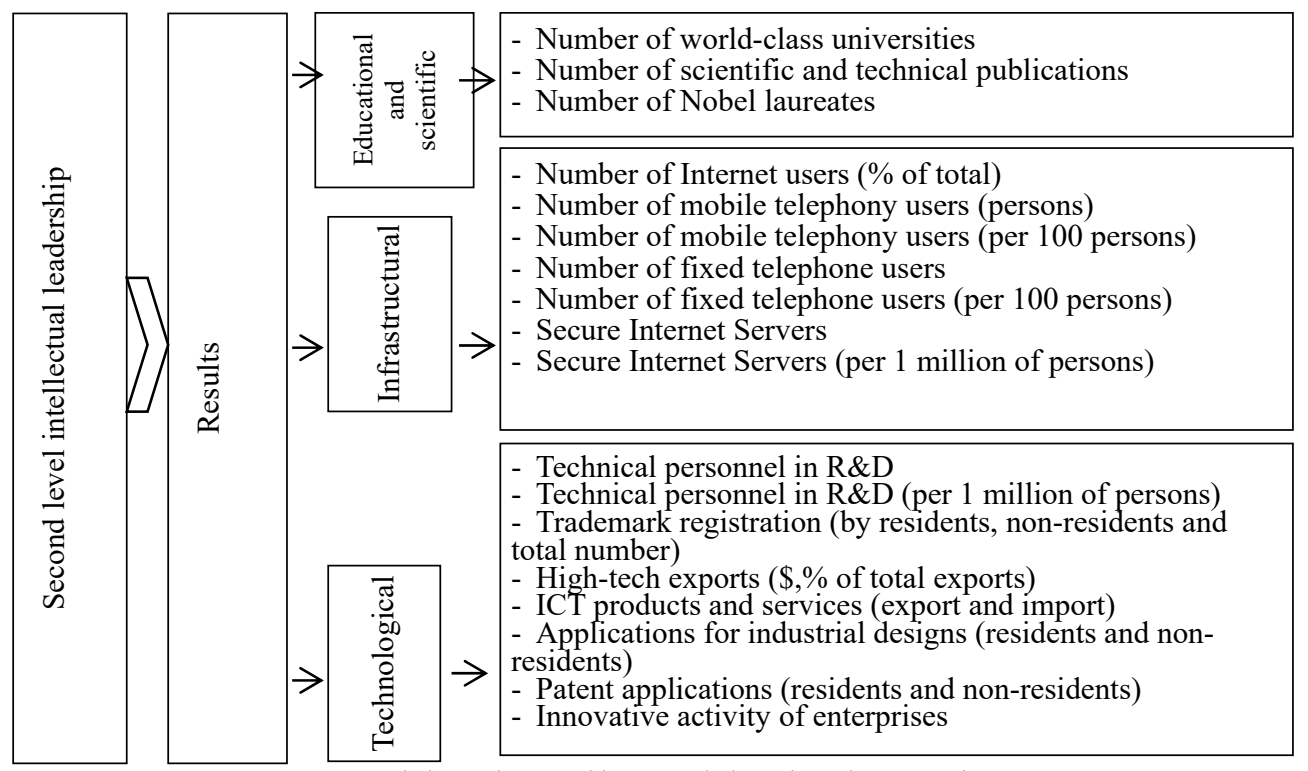

Fig. 3. Second-level intellectual leadership indicator system

\footnotetext{
${ }^{23}$ Systematized by the authors.
} 
importance of the intellectual component in the various world indices and ratings (Table 1). Only such a comprehensive and multi-component approach (subjective disposition together with selected levels of manifestation and a system of diversified indicators) makes it possible to assess the intellectual leadership of various subjects in a complex global environment.

Table 1

INTELLECTUAL COMPONENT IN GLOBAL RATINGS AND INDICES ${ }^{24}$

\begin{tabular}{|c|c|c|c|c|}
\hline & Indices, ratings & Organization & Indicators & Value \\
\hline \multirow{11}{*}{ 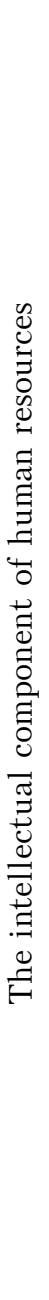 } & $\begin{array}{l}\text { Human Development } \\
\text { Index }\end{array}$ & UNO & $\begin{array}{l}\text { - Indicator of the level of } \\
\text { education }\end{array}$ & $\begin{array}{l}1 \text { subind. } \\
\text { of } 3 \\
5 \text { ind. of } \\
21\end{array}$ \\
\hline & $\begin{array}{l}\text { Index of the level of } \\
\text { education in the } \\
\text { world }\end{array}$ & UNO & $\begin{array}{l}\text { - Literacy level index } \\
\text { - Share of students }\end{array}$ & \begin{tabular}{|l|}
$2 / 3$ \\
$1 / 3$ of the \\
total value
\end{tabular} \\
\hline & $\begin{array}{l}\text { Index of social } \\
\text { progress }\end{array}$ & $\begin{array}{l}\text { The Social } \\
\text { Progress } \\
\text { Imperative }\end{array}$ & $\begin{array}{l}\text { - Availability of basic } \\
\text { knowledge } \\
\text { - Duration of women's education } \\
\text { - Duration of higher education } \\
\text { - Global ranking of universities } \\
\text { - Inequality in access to } \\
\text { education }\end{array}$ & $\begin{array}{l}5 \text { ind. of } \\
48\end{array}$ \\
\hline & $\begin{array}{l}\text { Global Innovation } \\
\text { Index }\end{array}$ & WIPO & $\begin{array}{l}\text { - Human capital and research in } \\
\text { the sub-index of innovation costs }\end{array}$ & 1 ind. of 6 \\
\hline & $\begin{array}{l}\text { Global Innovation } \\
\text { Index }\end{array}$ & $\begin{array}{l}\text { Bloomberg } \\
\text { Rankings }\end{array}$ & $\begin{array}{l}\text { - Tertiary efficiency }(5 \%) \\
\text { (coverage ratio for all subjects) }\end{array}$ & 1 ind. of 7 \\
\hline & $\begin{array}{l}\text { Global } \\
\text { Competitiveness } \\
\text { Index }\end{array}$ & WEF & $\begin{array}{l}\text { - Health and primary education } \\
\text { - Higher education and } \\
\text { vocational education }\end{array}$ & $\begin{array}{l}2 \text { groups } \\
\text { of } 12\end{array}$ \\
\hline & Prosperity Index & $\begin{array}{l}\text { Legatum } \\
\text { Institute }\end{array}$ & - Education quality indicator & $\begin{array}{l}1 \text { subind. } \\
\text { of } 8\end{array}$ \\
\hline & $\begin{array}{l}\text { Satisfaction with Life } \\
\text { Index }\end{array}$ & OECD & $\begin{array}{l}\text { - Indicator of availability of } \\
\text { education }\end{array}$ & $\begin{array}{l}\text { in } 1 \\
\text { subindex }\end{array}$ \\
\hline & $\begin{array}{l}\text { Academic Ranking of } \\
\text { World Universities }\end{array}$ & $\begin{array}{l}\text { Shanghai Jiao } \\
\text { Tong } \\
\text { University }\end{array}$ & $\begin{array}{l}\text { - Takes into account the activity } \\
\text { of leading universities and its } \\
\text { scale }\end{array}$ & $100 \%$ \\
\hline & $\begin{array}{l}\text { Webometrics Ranking } \\
\text { of World Universities }\end{array}$ & $\begin{array}{l}\text { Cybermetrics } \\
\text { Lab Spanish } \\
\text { National } \\
\text { Research } \\
\text { Council } \\
\end{array}$ & $\begin{array}{l}\text { - Takes into account Internet } \\
\text { activity of leading universities } \\
\text { and its scale }\end{array}$ & $100 \%$ \\
\hline & $\begin{array}{l}\text { World Trade } \\
\text { Organization Report }\end{array}$ & WTO & $\begin{array}{l}\text { - Includes of both primary and } \\
\text { secondary education coverage }\end{array}$ & $\begin{array}{l}2 \\
\text { indicators } \\
\text { of } 8\end{array}$ \\
\hline
\end{tabular}

\footnotetext{
${ }^{24}$ Systematized by the authors.
} 
Continuation of Table 1

\begin{tabular}{|c|c|c|c|c|}
\hline & Indices, ratings & Organization & Indicators & Value \\
\hline \multirow{5}{*}{ 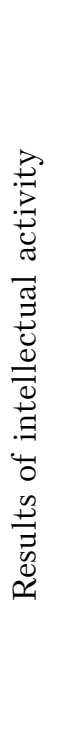 } & $\begin{array}{l}\text { Global Innovation } \\
\text { Index }\end{array}$ & WIPO & $\begin{array}{l}\text { - Sub-index of innovation costs } \\
\text { - Sub-index of innovation results }\end{array}$ & $100 \%$ \\
\hline & $\begin{array}{l}\text { Global Innovation } \\
\text { Index }\end{array}$ & $\begin{array}{l}\text { Bloomberg } \\
\text { Rankings } \\
\text { Agency }\end{array}$ & $\begin{array}{l}\text { - Intensity in the field of R\&D } \\
(20 \%) \\
\text { - High-tech density }(20 \%) \\
\text { - Concentration of researchers } \\
(20 \%) \\
\text { - Patent activity ( } 5 \%) \\
\text { - Technological capabilities }(10 \%)\end{array}$ & $\begin{array}{l}5 \\
\text { indicators } \\
\text { of } 7\end{array}$ \\
\hline & $\begin{array}{l}\text { Ranking of countries } \\
\text { by number of patents }\end{array}$ & WIPO & $\begin{array}{l}\text { - Takes into account specific } \\
\text { indicators of intellectual } \\
\text { performance }\end{array}$ & $100 \%$ \\
\hline & $\begin{array}{l}\text { Ranking of countries } \\
\text { by number of Internet } \\
\text { users; } \\
\text { mobile phone users; } \\
\text { export of hi-tech } \\
\text { products }\end{array}$ & $\begin{array}{l}\text { Compiled on } \\
\text { the basis of } \\
\text { statistics }\end{array}$ & $\begin{array}{l}\text { - Takes into account specific } \\
\text { indicators of intellectual } \\
\text { performance }\end{array}$ & $100 \%$ \\
\hline & $\begin{array}{l}\text { Global } \\
\text { Competitiveness } \\
\text { Index }\end{array}$ & WEF & $\begin{array}{l}\text { - Level of technological } \\
\text { development } \\
\text { - Innovative potential }\end{array}$ & $\begin{array}{l}2 \text { groups } \\
\text { of } 12\end{array}$ \\
\hline
\end{tabular}

We can identify global imperatives of intellectual leadership: resource (key role of human and intellectual capital), scientific and technological (no alternative to the transition to the format of paradigm 4.0 and 5.0); market (creation of new businesses and consumer needs), civilization (stability and universality of progress, sustainability and security of development).

\section{Assessment of the positions of individual countries in accordance with the author's methodology}

In accordance with the author's methodology for assessment of intellectual leadership, we will analyze the positions of individual countries according to these criteria. Thus, the defining trend of modern global development is the rapid growth of the number of students: it increased by $55 \%$ (from 140 million to 216 million people ${ }^{25}$ ) in total in all countries of the world from 2005 to 2016. At the global level, competition between countries and universities for attracting foreign students is intensifying, and the balance of power between the main centers of gravity is constantly changing. Along with the classic payers (USA, Germany, Canada, Australia, France, Great Britain, Japan,

\footnotetext{
${ }^{25}$ Enrolment in tertiary education, total number. URL: http://data.uis.unesco.org/\#
} 
etc.), new ones appear (China, Hong Kong, Brazil, Chile, Colombia, Greece, India, Slovakia, Slovenia and Ukraine), which due to such competitive advantages as price, image factor, low entry barriers, are increasingly claiming leadership status in the global educational space. Undoubtedly, the leading positions of the most developed countries are partly provided by significant financial investments in education and science, as the most developed countries have much higher expenditures on education than the average world index $\left(5.26 \%\right.$ of $\left.\mathrm{GDP}^{26}{ }^{27}\right)$. Thus, the most successful countries (Denmark, Finland, Norway and Sweden) spend more than $7 \%$ of GDP on education. There is a purposeful formation of the education-science-business chain in these countries, which is an important prerequisite for the transformation of the accumulated potential in the education system into real capital.

Competition is reaching a new level and is intensifying among the well-known research production centers (North America, Western Europe) and countries - new leaders (South and East Asia), which are more than $10 \%$ ahead of traditional leaders in terms of research funding. Such fierce competition has led to a global monopolization of the market, as USA and China together spend about $50 \%$ of total R\&D funding, and only 15 countries spend $85 \%$ of the world's total amount of funding ${ }^{28}$. The formation of world centers of scientific research is confirmed based on grouping the countries of the world by the level of GDP expenditures on R\&D (Table 2).

Table 2

GROUPING OF COUNTRIES BY LEVEL OF R\&D EXPENDITURE, \% of GDP, $2017^{29}$

\begin{tabular}{|c|c|c|c|c|}
\hline$>3 \%$ & $2-2.99 \%$ & $1-1.99 \%$ & $0.5-0.99 \%$ & $<0,49 \%$ \\
\hline $\begin{array}{l}\text { Sweden, } \\
\text { Austria, } \\
\text { Japan, } \\
\text { South } \\
\text { Korea, Israel }\end{array}$ & $\begin{array}{c}\text { Germany, Denmark, } \\
\text { Finland, Belgium, } \\
\text { Iceland, Norway, } \\
\text { Netherlands, } \\
\text { Slovenia, EU-27, } \\
\text { USA, China }\end{array}$ & $\begin{array}{l}\text { Great Britain, Czech } \\
\text { Republic, Italy, } \\
\text { Estonia, Portugal, } \\
\text { Luxembourg, } \\
\text { Hungary, Spain, } \\
\text { Ireland, Russia }\end{array}$ & $\begin{array}{c}\text { Greece, Poland, } \\
\text { Croatia, Slovakia, } \\
\text { Bulgaria, } \\
\text { Lithuania, Malta, } \\
\text { Cyprus, Serbia, } \\
\text { Turkey }\end{array}$ & $\begin{array}{c}\text { Romania, } \\
\text { Latvia, } \\
\text { Ukraine, } \\
\text { Georgia }\end{array}$ \\
\hline
\end{tabular}

Analysis of the structure of the countries-leaders in terms of the total number of scientific personnel and per thousand employees indicates significant differences in the list of leaders. The largest number of scientists in general is in China (3878 thousand), Japan (872 thousand), Russia (802 thousand), Germany (656.7 thousand), India (582 thousand),

\footnotetext{
26 Government expenditure on education as a percentage of GDP, selected countries. URL: http://data, uis, unesco,org/\#

${ }^{27}$ Government expenditure on tertiary education as a percentage of GDP (\%). URL:

$\mathrm{http}: / /$ databank.worldbank.org/data/reports.aspx?source=Education $\% 20$ Statistics

${ }_{28}$ Total expenditure on R\&D. URL: http://data.uis.unesco.org/\#

${ }^{29}$ Systematized by the authors according to the data from UNESCO, World Bank.
} 
South Korea ( 447.4 thousand) ${ }^{30}$. At the same time, all countries show a steady trend towards an increase in the total number of scientists.

In general, at the first level of intellectual leadership (resource) in the list of leaders are both classic highly developed countries and new players who are just beginning to take their places among the TOP countries: according to the indicators of the first level, the highest presence in all TOP-rankings is shown by Norway and Sweden; the second place belongs to Finland and Switzerland and the third position is shared by Australia, Brazil, New Zealand, South Korea and Japan.

A comprehensive analysis of intellectual leadership indicators at the level of intermediate results allowed to determine their importance for different groups of countries (developed countries and countriesfollowers). Thus, the result indicators are more important for the first cluster (those characterizing the readiness to innovate and realize their potential), these are the resource indicators for the second cluster. The polarization of the global economic environment in terms of effective indicators of intellectualization acquires the following characteristics: unconditional leadership of the United States in terms of the number of world-class universities and Nobel laureates; outpacing growth rates of scientific publications of Chinese and Indian scientists; formation of the main key centers of patent activity (China, USA, Japan, South Korea, Germany, India, Russia, Canada, Australia and Brazil). The accumulated patent potential of these countries is manifested in the increase of their presence in the market of high- and medium-tech products (production, export, import, ICT) (Fig. 4).

At the same time, developed countries (USA, Japan, Germany, South Korea, Great Britain, etc.) make significant investments in improvement of the existing technologies, development of breakthrough innovations and exponential technologies, however, countries with a lower level of development are focused on the initial stage of development. The focus of developed countries on the results of intellectual activity and effective public policy on their implementation in the economic realities has provided them with global leadership in terms of overall progress. This is evidenced by their presence in the vast majority of global rankings and indices that take into account indicators of intellectualization of economic activity (Global Innovation Index, Global Competitiveness Index, Human Development Index, Network Readiness Index, ICT Development Index, Economic Freedom Index, etc.).

\footnotetext{
30 Science, technology and innovation: Total R\&D personnel selected countries (in Full-time equivalents FTE and Headcounts - HC). URL: http://data, uis, unesco,org/\#
} 


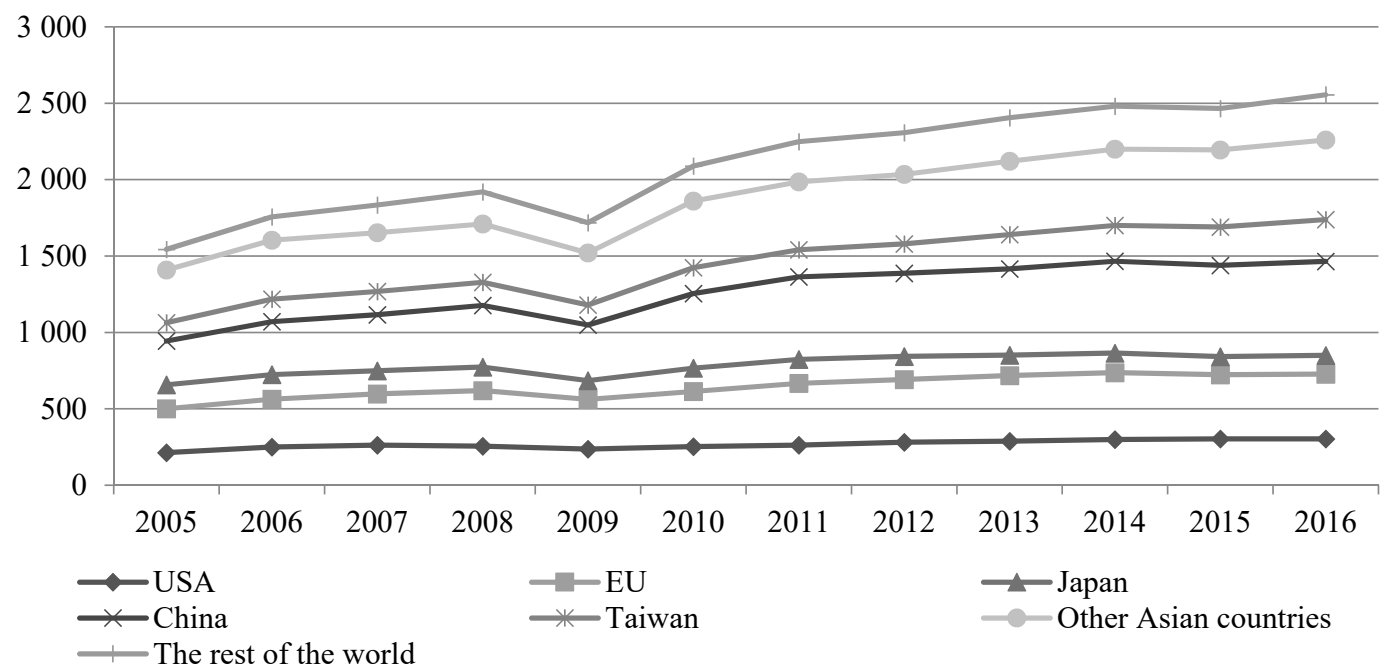

Fig. 4. Exports of high-tech products by selected regions, countries, 2005-2016, USD million ${ }^{31}$

The impact of intellectualization indicators on GDP of contries was analyzed with the help of multi-factor regression and cluster analysis and on the basis of the developed method, which made it possible to identify four clusters of countries that have common features and trends in social and economic development in key (static and dynamic) indicators of intellectual leadership (Table 3).

Table 3

\section{RESULTS OF CLUSTERIZATION OF COUNTRIES IN ACCORDANCE WITH INTELLECTUALIZATION INDICATORS}

\begin{tabular}{|c|c|}
\hline Cluster 1 & Cluster 2 \\
\hline $\begin{array}{c}\text { Australia; Austria; Belgium; Canada; Denmark; } \\
\text { Finland; France; Germany; Iceland; Ireland; Japan; } \\
\text { Luxembourg; Netherlands; Norway; Sweden; } \\
\text { Switzerland; UK; USA }\end{array}$ & $\begin{array}{c}\text { Czech Republic; Greece; Israel; } \\
\text { Italy; New Zealand; Portugal; } \\
\text { Slovenia; Spain }\end{array}$ \\
\hline Cluster 3 & Cluster 4 \\
\hline $\begin{array}{c}\text { Brazil; Chile; Colombia; Estonia; Hungary; Latvia; } \\
\text { Lithuania; Mexico; Poland; Russian Federation; } \\
\text { Slovakia; Turkey; Ukraine }\end{array}$ & $\begin{array}{c}\text { China; Hong Kong; India; } \\
\text { Republic of Korea; Singapore }\end{array}$ \\
\hline
\end{tabular}

${ }^{31}$ Science and Engineering Indicators 2018. URL: https:/www.nsf.gov/statistics/2018/nsb20181/report/ sections/industry-technology-and-the-global-marketplace/patterns-and-trends-of-knowledge--and-technologyintensive-industries

${ }^{32}$ Developed by the authors. 
The following models were formed on the basis on multilevel indicators of intellectual leadership: OLS (Combined Regression Model), FE (Fixed Effects Model), and RE (Random Effects Model), high determination coefficients are provided for these models $\left(\mathrm{R}^{2}=\right.$ 0.972 for the OLS model and $\mathrm{R}_{\text {within }}^{2}=0.781$ for the $\mathrm{FE}$ model) and a statistically significant Wald criterion for the RE model, which indicates the high quality of each of them, but given the peculiarities of the economic systems of the countries, the model that best describes our data is the Fixed Effects Model:

for the resource level:

$$
\begin{aligned}
& \left.G D P_{i t}=\underset{(0,297 * * *)}{4,471}-0,067 \text { total_mobil }_{i t}+0,002 e d u c_{-} g o v_{-} \exp _{i t}+0,068 g o v_{-} \text {tertiary } \_ \text {GDP } i t\right)- \\
& 0,159 \text { gov_educ_GDP } i t+0,152 R D_{-} \text {persons }_{i t}+0,782 \text { gov_educ }_{i t} \text {, } \\
& (0,016 * *) \quad\left(0,035^{* * *}\right) \quad(0,027 * * *)
\end{aligned}
$$

for the level of intermediate results of economic activity:

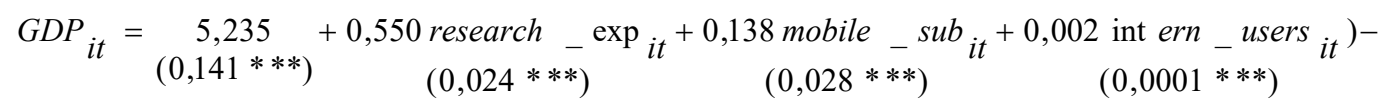

$$
\begin{aligned}
& 0,016 \text { hi-tech _ } \exp _{i t}-0,018 \text { patent } \_ \text {res }{ }_{i t}+0,170 \text { trademark }-{ }^{\text {nres }} \text { it } \\
& (0,015) \\
& (0,015) \\
& (0,016 * * *)
\end{aligned}
$$

Econometric modeling allows to determine the closeness of the relationship among different levels of indicators and to identify the most significant factors in achievement of intellectual leadership in different countries. Thus, for the countries of the first cluster, the important factors of influence are the financing of education (provided that the share of state participation in these processes is reduced), the number of research personnel and significant involvement of these countries in international student mobility, research and development costs (1\% increase leads to an increase of GDP by $0.5 \%$ ), high-tech exports, involvement of non-residents in patent activity. For the countries of the second cluster, the growth of expenditures on education is positive ( $1 \%$ increase leads to an increase of GDP by 1\%), the development of the information and communication sector (availability of secure Internet servers, Internet speed), participation in the processes of international student mobility and the growth of the share of high-tech exports have negative effects. For the group of countries belonging to the third cluster, the level of expenditures on education and higher education is most influential, in particular, diversification of sources of funding for education, increase in the number of scientific personnel, increase in the patent activity of non-residents, level of expenditures on research and development, growth of high-tech exports. In the fourth cluster, the number of scientific personnel, the availability of information infrastructure, the growth of high-tech exports have the biggest positive 
impact. Analysis of strategies to achieve leadership of key innovators and global leaders, which in the vast majority of global rankings are in the top 10 in terms of resource and performance indicators, shows that most countries use a multi-component portfolio of mechanisms and tools to intensify intellectual activity (Table 4). A characteristic feature of strategic measures of developed countries for the achievement of intellectual leadership is accumulation of their potential (domestic, external, use of synergy effects from international collaborations) and the creation of favourable conditions for its implementation and transformation into capital.

Table 4

MATRIX MODEL OF KEY MEASURES' IMPLEMENTATION BY INDIVIDUAL COUNTRIES-LEADERS ACCORDING TO THE GENERAL PROGRESS INDICATORS ${ }^{33}$

\begin{tabular}{|c|c|c|c|c|c|c|c|c|c|c|}
\hline Analyzed measures & 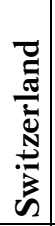 & 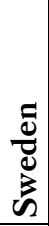 & 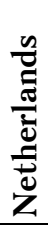 & $\underset{\mathscr{S}}{\widetilde{D}}$ & 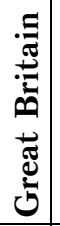 & 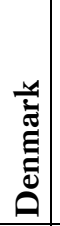 & 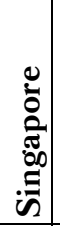 & 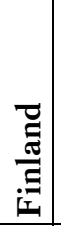 & 哥 & 疍 \\
\hline $\begin{array}{l}\text { Tax benefits (R\&D expenditure) } \\
\text { Preferential taxation of venture and scientifically } \\
\text { active enterprises }\end{array}$ & + & & & $\begin{array}{l}+ \\
+\end{array}$ & $\begin{array}{l}+ \\
+\end{array}$ & & & & $\begin{array}{l}+ \\
+\end{array}$ & + \\
\hline $\begin{array}{l}\text { Stimulation of the increase in the number of pupils and } \\
\text { students specializing in STEM }\end{array}$ & + & + & & + & & & & + & & \\
\hline $\begin{array}{l}\text { Stimulation of the increase in the number of students } \\
\text { and people with higher education }\end{array}$ & + & + & + & & & + & & + & + & \\
\hline High level of R\&D state funding & + & + & & + & & + & + & + & + & \\
\hline $\begin{array}{l}\text { Stimulation of the increase in the presence of private } \\
\text { capital in the } R \& D\end{array}$ & + & + & & + & + & & & & + & + \\
\hline Reduction of tax rates for foreign companies & + & & & $++^{*}$ & + & & & & & \\
\hline $\begin{array}{l}\text { Promotion of the participation of national companies } \\
\text { in global networks }\end{array}$ & + & & + & + & + & & + & + & & + \\
\hline $\begin{array}{l}\text { Agencies and platforms that help bring universities and } \\
\text { businesses together }\end{array}$ & & + & + & + & + & + & + & + & & + \\
\hline $\begin{array}{l}\text { Formation of innovation regions (clusters) and } \\
\text { focusing on their development }\end{array}$ & & & + & & + & + & + & + & + & + \\
\hline Return of their own scientists from abroad & & & & & & & + & & & + \\
\hline $\begin{array}{l}\text { Attraction of immigrants to promote innovative } \\
\text { development }\end{array}$ & & & & + & & & & & & \\
\hline $\begin{array}{l}\text { Formation of the leading physical infrastructure and } \\
\text { digital infrastructure of the next generation }\end{array}$ & & & & + & & & + & + & & + \\
\hline
\end{tabular}

* Subject to certain conditions.

${ }^{33}$ Systematized by the authors. 
The result of the long evolution of development strategies was the formation of a multilevel complementary model of support for the processes of active intellectualization, taking into account the national characteristics of the countries. The analysis of strategies of intellectualization of economic development of the countries-new leaders and the countries-followers has allowed to reveal the following tendencies. Countries that choose priorities and use different approaches to breakthrough development are the most successful: the most developed countries form strategies for the sustainable development of high-tech sectors (USA, Western Europe, Japan, etc.). The countries new leaders are implementing innovative breakthrough strategies (South Korea, Singapore, Israel, China, Brazil, India, etc.). At the same time, developing countries (Chile, Mexico, etc.) are prone to sectoral concentrations with increasing value added in traditional industries.

The generalization of national models of development and innovation policy makes it possible to single out a country's breakthrough development models that focus on sectoral dimensions (development of only dominant sectors of the economy as a source of intellectual leadership - Digital India ${ }^{34}$, Techno City ${ }^{35}$, SERCOTEC $^{36}$, SPYME ${ }^{37}$, National Science ${ }^{38}$ and others). The modern system of regulation and management of intellectualization processes is characterized by the establishment of intellectual property, effective functioning of the national innovation system, accelerated integration of science, education and business, development of research and educational infrastructure, creation of innovative national and international clusters, platforms, networks, digital transformation of science and education institutions. This allows to institutionalize the processes of intellectualization, to develop an appropriate national strategy, to form a portfolio of necessary administrative, legal, economic and motivational mechanisms and tools for intensification and scaling of intellectual activity.

\section{Place of Ukraine on the global map of intellectual development}

The fundamental provisions for the intensification of the intellectualization of Ukrainian economic activity on the basis of identification of the strengths and weaknesses of the national economy

\footnotetext{
${ }^{34}$ Digital India. A programme to transform India into a digitally empowered society and knowledge economy. URL: http://meity.gov.in/sites/upload files/dit/files/Digital\%20India.pdf

${ }^{35}$ Konza Techno City Kenya, 'Māster Plan'.URL: http://www.konzacity.go.ke/ the-vision/master-plan/

36 Andes S., Ezell S.J., LealJ. An Alternative to Mercantilism: Manufacturing Extension Services in Latin American and Caribbean Countries. Washington, DC: ITIF. 2013. URL: http://www2.itif.org/2013manufacturingextension-services-latin-america-caribbean. pdf.

${ }^{37}$ Ibid. Cepeda R.C., Lippoldt D.C., SenftJ. Policy Complements to the Strengthening of IPRS in Developing Countries. OECD Trade Policy Papers. 2010, No. 104. URL: http://dx.doi.org/10.1787/5km7fmwz85d4-en
} 
were substantiated. The following strong points were identified: relatively high level of ICT infrastructure development; highly skilled workforce; low cost of education; attractive cost-effective higher education system for international students; mosaic high price of innovation and technological infrastructure, which especially characterizes the business sector; development of the industrial sector and significant development potential, especially in the agro-industrial sector; availability of a developed resource base and opportunities for its development and efficiency; significant market volumes, which allows companies to grow and expand. The following weak points were identified: lack of a clear strategy for innovative development and state support for innovation; low GDP growth rates; low share of business sector expenditures on research and development, high-tech exports, investment in research and development; weak focus on educational policy, lack of purposeful strategy for the development of the education system; a small number of internationally competitive firms and a weak link between the business sector and science; low productivity of the services sector. Identified opportunities and threats become the basis for priority areas of development and intensification of the use of Ukraine's intellectual potential in the process of globalization.

Based on the conducted analysis of indicators of intellectual leadership of Ukraine and their impact on its GDP, the forecast of the level of economic development for 2016-2020 was made using econometric modeling and it confirmed the reliability of the model, as the calculations relate to the present period as well. At the first stage, one-factor linear regressions of the influence of each independent variable on the value of GDP were identified and it was determined that there are three indicators that have the greatest level of influence on the GDP size at the level of resources, namely: government expenditures on higher education, government expenditures on education and the number of degree seekers. Among the result indicators, the number of mobile phone users, high-tech exports, ICT exports, industrial design and trademark claims by non-residents and their patent activity, research and development costs have a substantive and statistically significant impact on GDP in the age of digital technology. On this basis, the development of Ukrainian economy was forecast in accordance with the baseline and optimistic scenarios (in the baseline scenario, the values of independent variables for the forecast are taken as a continuation of the 2005-2015 trend; in the optimistic scenario, the values of independent variables are $5 \%$ higher than baseline values).

For all models, the value of the reliability of the data approximation by different types of trends differs slightly, but the best specification is 
the rectilinear regression, which was used to build a forecast for 20162020. The conducted forecast was tested by real data on Ukrainian GDP development, according to which the most appropriate forecast is based on research and development expenditures, which indicate GDP growth per capita subject to an increase in research expenditures, which confirm the thesis of the priority of science for economic development and achievement of its competitive positions (Fig. 5).

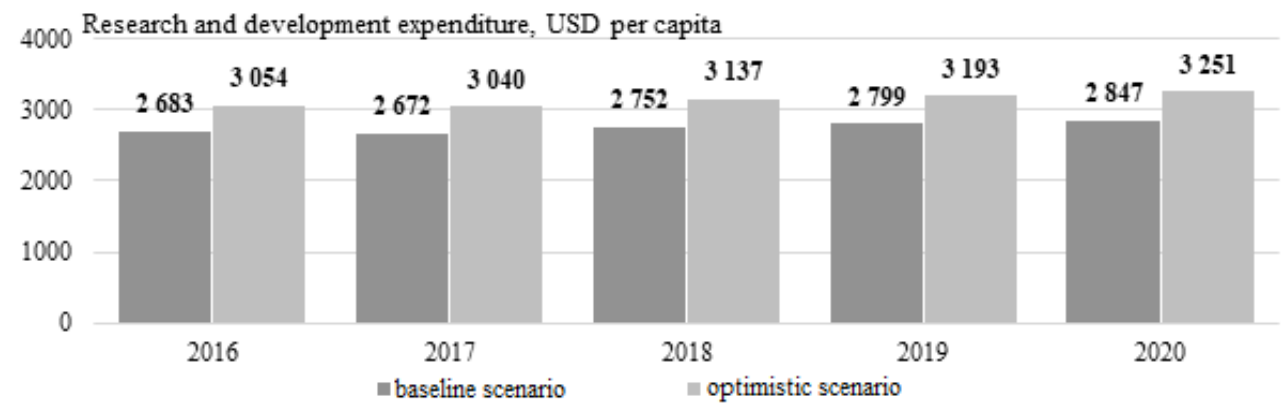

Fig. 5. Forecasting GDP dynamics based on one-factor econometric models (result factors influencing the GDP size) ${ }^{39}$

The conducted analysis revealed that the success of Ukraine in achievement of intellectual leadership in certain segments of the global economic environment is determined by the presence of necessary and sufficient prerequisites, the implementation of which is possible only with a balanced government policy to enhance the intellectual potential of the country, taking into account the best world practices for increase of the intellectual capital assets. It is extremely important to maximize the stimulation of innovation activity of both residents and nonresidents, intellectual activity and the formation of an institutional environment favorable for increase of the intellectual capital assets and its successful, cost-effective implementation. We believe that it is especially important to give the education and science systems a priority status in the state, given their crucial role in the formation of an intellectual economy.

\section{Conclusion}

The study of the nature and forms of intellectual leadership in global competition suggests that the imperatives of intellectualization and innovation are becoming the key ones in the evolution of global

${ }^{39}$ Developed by the authors. 
economic development. The complex characteristics of the intellectualization of the global economy by the author's assessment method testified the existence of global asymmetries of intellectualization on national and regional grounds. As a result of complex evolution, the world's leading countries are becoming the driving force of STP, increased intellectualization of production, the introduction of innovations primarily in high-tech sectors of the economy. For developing countries, the issues of accumulation of intellectual potential and creation of opportunities for its implementation are relevant. Intellectualization and leadership are beginning to manifest themselves not only as the result of the activities of one subject, but also as a synergistic effect of collaboration and active cooperation among countries, forming new globalization effects.

In the process of formation of the global innovation space, an extensive multilevel system of generation and commercialization of innovations for their widespread market implementation is being formed, because in the period of increasing global competition, the increase in funding for fundamental and applied science leads to an increase of key macroeconomic indicators according to the results of econometric modeling.

Ukrainian place in the global intellectualized economic space can be improved due to the availability and functioning of a purposeful state policy of economic development intellectualization, which in its turn requires the development of a state innovation strategy based on the priority of science and knowledge intensive industries, promotion of the creation of innovation-oriented clusters, support of business participation in knowledge-intensive sectors of the economy.

\section{References}

1. Andes S., Ezell S.J., LealJ. An Alternative to Mercantilism: Manufacturing Extension Services in Latin American and Caribbean Countries. Washington, DC: ITIF. 2013. URL: http://www2.itif.org/2013-manufacturingextension-serviceslatin-america-caribbean. pdf.

2. Antonyuk L. International competitiveness and regional aspect. International Economic Policy. Vol. 2 (1). K.: KNEU, 2005. pp. 44-68.

3. Blanchard K. Leadership: to the pinnacle of success. SPb .: Piter, 2008. $-368 \mathrm{p}$.

4. Blondel J. Political Leadership: Towards a General Analysis. LondonBeverly Hills-New Delhi: SAGE Publications, 1987. -216 p.

5. Butnik-Siversky O. Intellectual capital: a theoretical aspect. Intellectual capital. 2002. No.1. - pp. 16-27.

6. Ca de Vrie Manfred. The mystique of leadership. Development of emotional intelligence. M .: Alpina Publishers, 2003. - $311 \mathrm{p}$.

7. Cepeda R.C., Lippoldt D.C., SenftJ. Policy Complements to the Strengthening of IPRS in Developing Countries. OECD Trade Policy Papers. 2010, No. 104. URL: http://dx.doi.org/10.1787/5km7fmwz85d4-en 
8. Chukhno A. Intellectual capital: the essence, forms and patterns of development (ukr. Intelektualnyi kapital: sutnist, formy i zakonomirnosti rozvytku). Ukraine economy (ukr. Ekonomika Ukrainy). 2002. No. 11. - pp. 4855. [In Ukrainian].

9. Digital India. A programme to transform India into a digitally empowered society and knowledge economy. URL: http://meity.gov.in/ sites / upload_files / dit/files / Digital\%20India.pdf

10. Hollander E. Conformity, Status and Idiosyncrasy Credit. Psychological Review, 1958. No.65. - pp. 117-127.

11. Government expenditure on education as a percentage of GDP, selected countries. http://data.uis.unesco.org/\#

12. Government expenditure on tertiary education as a percentage of GDP (\%). http: / / databank. worldbank.org / data/reports.aspx?source=Education\%20Statistics

13. Katz D. Pattern of Leadership, in J.Knutson (ed.), Handbook of Political Psychology, San Francisco: Jossey-Bass, 1973. - pp. 203-233
14. Konza
Techno
City
Kenya,
'Master
Plan'.URL:

http: / / www.konzacity.go.ke/ the-vision / master-plan/

15. Kuczmarski, S., Kuczmarski, T. Values-Based Leadership. Book Ends Publishing, Chicago, 2002. - 304 p.

16. Kuklin O. Institutional analysis of interregional socio-economic convergence in the context of European integration: interdisciplinary methodological approach development. Baltic Journal of Economic Studies. 2019, No.5. - pp. 80-85.

17. Lukyanenko D., Kolesov V., Kolot A., Stolyarchuk J. Global economic development: trends, asymmetries, regulation: a monograph (rus.. Globalnoe ekonomicheskoe razvitie: tendentsii, asimmetrii, regulirovanie: monografiya) / ed.: D. Lukyanenko, A. Poruchnik, V. Kolesov. K .: KNEU, 2013. -466 p. [In Russian].

18. Lukyanenko D.G., Poruchnik A.M., Kolot A.M. and other. Global economy of the XXI century: human dimension: monograph (ukr. Hlobalna ekonomika XXI stolittia: liudskyi vymir: monohrafiia) / edited by Dr. Econ. Science, prof. DG Lukyanenko and Dr. of Economics, Prof. A.M. Poruchnik. K. KNEU, 2008. - 420 p. [In Ukrainian].

19. Macfarlane B. Intellectual Leadership. 2011. URL: https://www.kcl.ac.uk /study / learningteaching/kli /NewsandEvents / Events /scap/2011/macfarlanescap2011.pdf.

20. Mitchell D., Nielsen S. Internationalization and Globalization in Higher Education. Globalization - Education and Management Agendas, 2012. - pp. 322. URL: https: / / pdfs.semanticscholar.org/3e6c / 1173f21907959cd4d1fe47 ab4109795 f50d9.pdf

21. Owen H. Vocation - Leader: A Complete Guide to Effective Leadership. Dnipropetrovsk: Balance Business Books, 2005. - 384 p.

22. Senge P., Kleiner A., Roberts C., Ross R., Smith B. The Fifth Disciplines Fieldbook: Tools and Strategies for Building a Learning Organization, New York: Doubleday / Currency, 1994.

23. Stogdill R., Bass B. Handbook of Leadership. 3 Sub edition. N.Y.: Free Press, 1990. - $1184 \mathrm{p}$. 
24. Sidenko S. A Socially Orientated Development Model of Ukraine. A Social and Solidarity Economy. The Ukrainian Choice. / Edited by Anton S. Filipenko. Cambridge Scholars Publishing. 2017. - pp.44-60.

25. Science, technology and innovation: Total R\&D personnel selected countries (in Full-time equivalents - FTE and Headcounts - HC). URL: http: / / data.uis.unesco.org/\#

26. Science and Engineering Indicators 2018. URL: https://www.nsf.gov/ statistics / 2018 /nsb20181 / report / sections / industry-technology-and-the-globalmarketplace / patterns-and-trends-of-knowledge--and-technology-intensiveindustries

27. UNESCO. Total expenditure on R\&D. URL: http://data.uis.unesco.org /\#

28. UNESCO. Education Indicators. URL: http://data.uis.unesco.org/\#

29. Weber M. Three pure types of legitimate domination. Sociology. General historical analyzes. Policy. K.: Osnovy, 1998. - pp.156-172.

30. World Bank. Government expenditure on tertiary education as a percentage of GDP (\%). URL: http://databank.worldbank.org/data/ reports.aspx? source=Education $\% 20$ Statistics

The article was received by the Editorial Board on February 04, 2020. 